\title{
In Vitro Bioaccessibility of Lead in Artisanal Mining Contaminated Soils and Sediments from the Anka Area, NW Nigeria
}

\author{
Nuhu Musa Waziri ${ }^{1}$ \& Julian E. Andrews ${ }^{2}$ \\ ${ }^{1}$ Department of Geology, Federal University of Technology, Minna, Nigeria \\ ${ }^{2}$ School of Environmental Sciences, University of East Anglia, Norwich, UK \\ Correspondence: Nuhu Musa Waziri, Department of Geology, Federal University of Technology, Minna, Nigeria. \\ Tel: 234-810-200-7797. E-mail: nuhuwaziri@futminna.edu.ng
}

\author{
Received: August 1, 2013 Accepted: September 20, 2013 Online Published: December 6, 2013 \\ doi:10.5539/esr.v3n1p1 URL: http://dx.doi.org/10.5539/esr.v3n1p1
}

\begin{abstract}
The gastric bioaccessibility of $\mathrm{Pb}$ was investigated in soils and sediments from five villages in the Anka area of north-western Nigeria which has been adversely affected by artisanal mining of gold from lead-rich ores. In vitro bioaccessibility experiments were used to determine the extractability of $\mathrm{Pb}$ in order to evaluate the human health risk, especially to children below the age of five. The concentration of $\mathrm{Pb}$ in the simulated gastric fluids ranges from $\sim 198$ to $41740 \mu \mathrm{gg}^{-1}$ (mean, $9732 \mu \mathrm{gg}^{-1}$ ), with corresponding human bioaccessible fraction between $\sim 29$ and 100\% (mean, $\sim 60 \%$ ). Chemical daily intake (CDI, $\mu \mathrm{g} / \mathrm{Kg} / \mathrm{Day}$ ) values of between 111 and 41587 are generally very high compared to the tolerable daily intake (TDI) of $\sim 3.6 \mu \mathrm{g} \mathrm{Pb} / \mathrm{Kg} / \mathrm{Day}$. The high bioaccessibility is a result of high total concentration of $\mathrm{Pb}$ and the presence of highly soluble carbonate and oxide minerals in the ores. These results point to the very adverse health effects likely to result from incidental hand-to-mouth ingestion of soils by children in the affected villages. The results further show that the low $\mathrm{pH}$ of gastric juices enhances the extraction of $\mathrm{Pb}$. Given the likelihood of sub-nutrition in the affected communities, characterized by skipping of meals, which can result in lowering of the $\mathrm{pH}$ over extended periods, the risk of $\mathrm{Pb}$ poisoning is further increased. This study was based on a hand-to-mouth ingestion scenario alone, but as other exposure routes, such as eating improperly washed vegetables and inhalation of dust are possible, the risk might even be higher. This, along with the fate of extracted $\mathrm{Pb}$ in the intestinal environment may need to be evaluated in order to fully quantify the bioavailability of $\mathrm{Pb}$ in the area.
\end{abstract}

Keywords: artisanal mining, lead, in vitro bioaccessibility, contaminated soil

\section{Introduction}

Since the dawn of civilization, we have continually exploited minerals and rocks for the production of goods, energy and building materials (Hudson-Edwards et al., 2011) with its attendant environmental consequences. Mining results in a variety of wastes, ranging from host rock debris and its associated gangue minerals, to dusts from milling, to slag resulting from smelting operations. These, often potentially toxic element (PTE, Alloway, 1995) laden wastes serve as sources of contamination in the environment and provide pathways for human exposure. In many parts of the world, metalliferous mining activities have been shown to lead to heavy metal contamination of soils, sediments and water (Adriano, 1986; Thornton, 1996; Jung, 2001; Bird et al., 2003; Dolenec et al., 2007). In the Anka region of north-western Nigeria, exploitation of gold and associated sulfide minerals by artisans is a common practice and has led to severe contamination of soils and stream sediments. Environmental problems related to artisanal gold mining are widely reported in the developing world, for example, Ghana (Hilson, 2002; Babut et al., 2003); Ecuador (Appleton et al., 2001) and the Brazilian Amazon (Hinton et al., 2003). Artisanal mining and beneficiation methods are often very crude and under little or no regulation, leading to widespread improper disposal of mine wastes and contamination (Hilson, 2002).

As a result, elevated levels of the PTEs may be found in and around metalliferous mines due to the dispersion of mine wastes down slope by surface runoff, wind action and effluent drainage into nearby soils and open water systems (Jung, 2001). One implication of having excessive levels of these elements in soils is that crops may take them up and pass them through the food chain to human beings. Another route of transmission to humans, especially children, is hand to mouth ingestion, in addition to contamination of surface and groundwater resources and inhalation of dusts. 
Little has so far been done to investigate the environmental impact of artisanal gold mining in general and soil heavy metal concentrations and bioaccessibility in this and other areas of Nigeria. As pointed out by Olade (1987), most studies on the biogeochemical cycling of heavy metals have been within temperate or sub-tropical ecosystems and therefore little is known about their behaviour in the semi-arid tropics, such as northern Nigeria. A recent outbreak of acute lead poisoning among rural dwellers of the Anka area, which killed hundreds of children (UNEP/OCHA, 2010) has been traced to artisanal mining and processing of gold from a mainly galena-chalcopyrite ore deposit. In fact, the work conducted by UNEP reported concentrations of up to 60,000 $\mu \mathrm{g} / \mathrm{g}$ lead in the soil of some villages while the Blacksmith Institute (2011) reported soil lead concentrations in seven villages to be in excess of $100,000 \mu \mathrm{g} / \mathrm{g}$, resulting in blood lead levels in children generally exceeding the internationally acceptable limit of $10 \mu \mathrm{g} / \mathrm{dl}$. These results are similar those obtained in two villages in this area by Dooyema et al. (2012).

It is therefore vital to study the effect of these small-scale mines on the quality of the environment and the possible human health risks incident upon potentially toxic element contamination of soils and sediments in the area. To address this gap, the present work has investigated the geochemistry of soils and sediments from Anka in the north-western Nigeria schist belts, with particular focus on the relative in vitro bioaccessibility of lead.

Knowledge of total metal concentration in environmental matrices alone is not enough in assessing bioavailability, mobilization and the human risk in an environment. Neither does the total concentration provide a good indication of the levels of metals potentially available to plants (Ullrich et al., 1999). In vitro bioaccessibility tests (IVBA) are inexpensive, physiologically-based extraction tests (PBET) designed to estimate the bioaccessibility of elements along exposure pathways (Morman et al., 2009). This is achieved by measuring the geochemical reactivity of the materials in simulated body fluids such as saliva, lung fluids and gastric juices or blood plasma. It is used as a proxy for the more complicated, expensive and often ethically constrained measurements of bioavailability using in vivo methods involving the use of animal or human subjects. Bioaccessibility in relation to human exposure by ingestion has been defined by Ruby et al. (1999) as the fraction of a potential toxicant in earth materials that becomes solubilised in the stomach or lungs, thus becoming available for absorption. For a given toxicant such as a potentially toxic element, the total concentration in an earth material is far more than the quantity eventually absorbed into the circulatory system of a subject (Plumlee \& Ziegler, 2004). This means that, bioavailability < bioaccessibility $<$ total concentration of a contaminant in an earth material.

Several methods of performing the in vitro studies have been reported in the geochemical literature. For example, Medlin (1997) used a fluid containing pepsin, admixed with citric, malic, lactic, acetic and hydrochloric acids. The method of Drexler and Brattin (2007) which was adopted by Morman et al. (2009) advances the combination of concentrated hydrochloric acid and glycine in deionised water. The approach of EPA (2008) involved combinations of sodium chloride, pepsin with hydrochloric acid and sodium bicarbonate, bile salts and pancreatin for the stomach and intestinal phases respectively. This two stage procedure earlier reported by Cave et al. (2006) was adopted by Button et al. (2009), while investigating the risk to humans at arsenic contaminated sites at a former mine at the Devon Great Consols, southwest England. However, the EPA (2008) in a subsequent study appeared to question the necessity of using the complex fluids. They argued that when the bioaccessibility of a series of test substances were compared using $0.4 \mathrm{M}$ glycine buffer at $(\mathrm{pH} 1.5)$ with and without the enzymes and metabolic acids, no significant difference was observed. They therefore concluded that the simplified buffer employed is appropriate, even though it lacked some constituents known to be present in gastric fluids: this is the method used in the present study.

\section{The Study Area}

The study area (Figure 1), which covers about $990 \mathrm{~km}^{2}$, is in the Anka local government area of Zamfara State in the north-western part of Nigeria. It falls between latitude $11^{\circ} 51^{\prime} \mathrm{N}$ and $12^{\circ} 08^{\prime} \mathrm{N}$, and longitude $5^{\circ} 51^{\prime} \mathrm{E}$ and $6^{\circ} 08^{\prime} \mathrm{E}$ and is characterized by generally gentle relief. The main surface water body in the area is the Anka River, which lies about a kilometre to the north of the town and numerous seasonal streams dissect the landscape, feeding into the main river. Many of these streams are used as sources of water for domestic use, irrigation and livestock watering, especially during the wet season. Vegetation in the entire region is generally sparse, and has been described by Russ (1957) as savannah forest together with scrubs, which thin out in a northerly direction, with semi- deciduous high forests along streams and depressions. Generally, the inhabitants of this area are farmers, who are engaged in the cultivation of a large number of cereal and vegetable crops. 


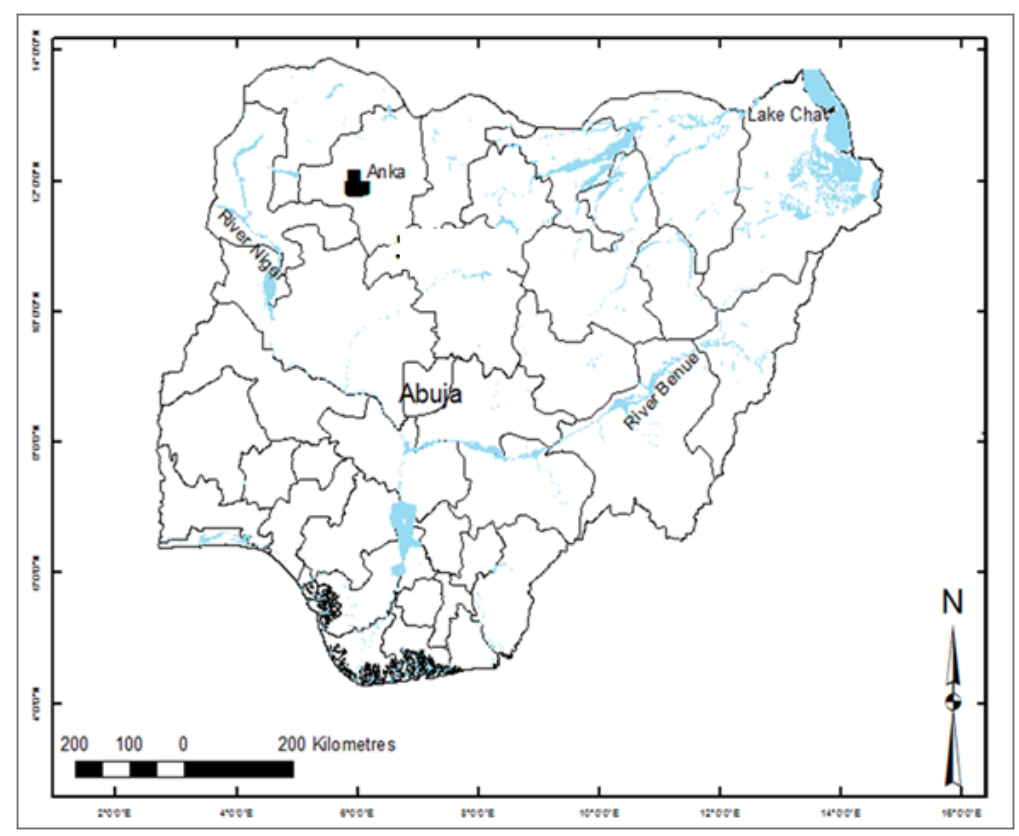

Figure 1. Outline map of Nigeria showing the location of the study area (modified from Waziri, 2012)

Geologically, the study area is in the Schist Belt of the Nigerian basement complex which is part of the Pan-African mobile belt, sandwiched between the West African Craton and the Congo Craton. It has been described by McCurry and Wright (1977) as a system of synclinorial belts of low-grade metasediments, downfolded into high-grade gneisses and migmatites, the whole intruded by batholitic granites. Metamorphism in these belts is generally of low grade, falling within the green-schist facies and characterized mainly by schists, phyllites, banded iron formations, carbonate rocks and mafic metavolcanics which are now in the form of amphibolites and meta-conglomerates (Turner, 1983). These and the migmatite-gneiss basement have been cut by Pan-African granites.

Like many other similar geological belts in Nigeria and the entire West African region, the Anka area has been the focus of artisanal gold exploitation for several decades. Gold in this area is hosted by schists, phyllites and quarzites related to sub-regional structural elements subsidiary to the Anka fault (Garba, 2003) and metaconglomerates (Russ, 1957). The gold mineralizing fluids, based on $\mathrm{Na}_{2} \mathrm{O} / \mathrm{Al}_{2} \mathrm{O}_{3}-\mathrm{K}_{2} \mathrm{O} / \mathrm{Al}_{2} \mathrm{O}_{3}$ discrimination diagrams and inter-lithophile elements ratios are interpreted to be of metamorphic origin (Danbatta et al., 2009). The mineralized concordant veins are generally short, not exceeding half a kilometre of strike length and trace metal concentration in altered wall rock reported by Garba (2003) of 647-5410 ppm Cu; 7550-22600 ppm Pb; 1.5-8.6 ppm Ag and 123-6320 ppb Au show that the ores are very rich in lead and copper minerals, mostly galena which was observed during field work and identified in the contaminated soil using SEM (Figure 2) and also chalcopyrite. 


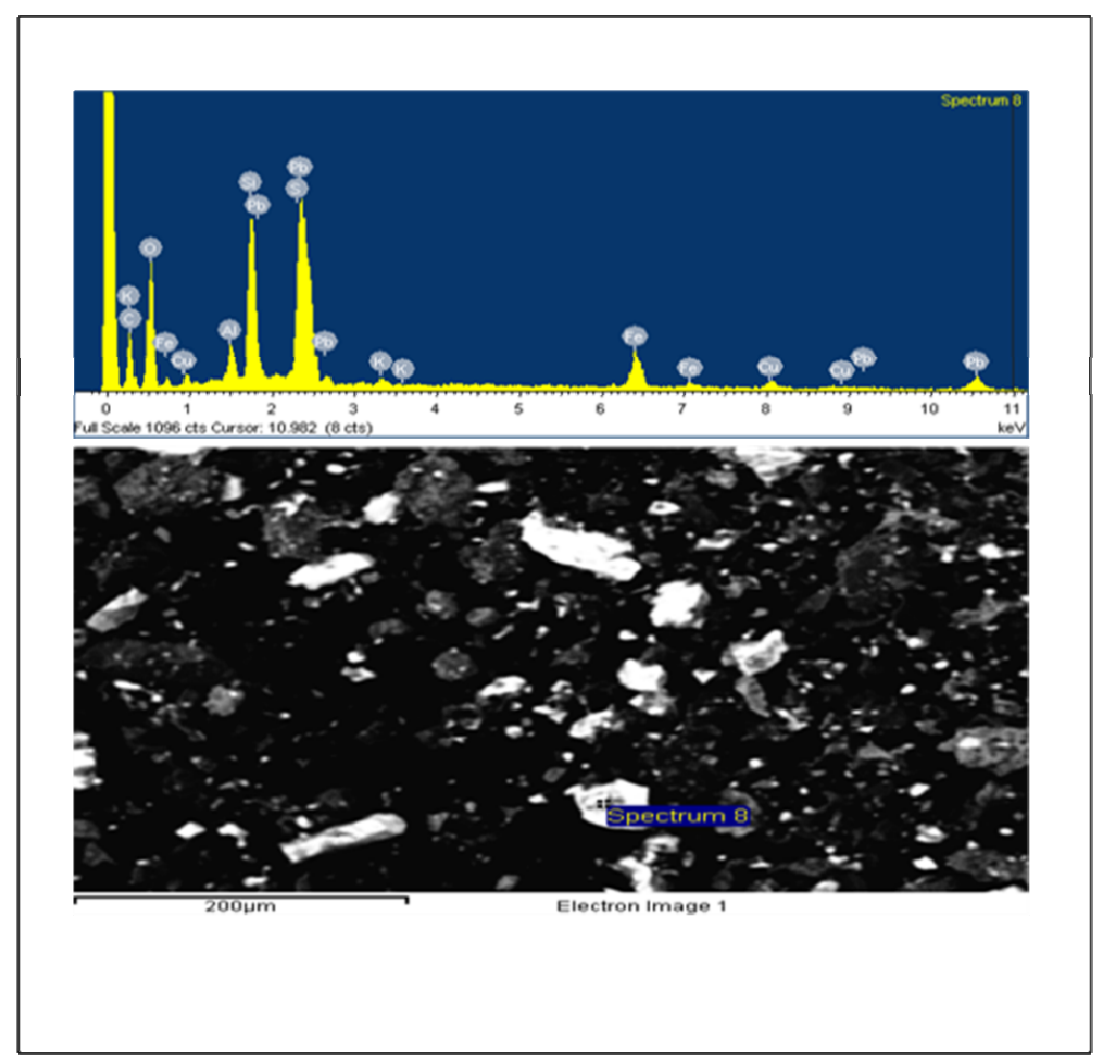

Figure 2. SEM micrograph and EDS spectra for a highly contaminated soil sample from Anka area, showing widespread lead minerals (light particles) in the sample. The particle sizes, generally less than $200 \mu \mathrm{m}$ make them very amenable for hand-to-mouth ingestion and suspension as dusts

\section{Methodology}

\subsection{Fieldwork}

Top soil and sediment samples were taken from the vicinity of mines and within the villages where ore processing has taken place. Samples were collected from 0 to $15 \mathrm{~cm}$ depth using a plastic trowel and placed in plastic self-seal bags. At each sampling point, three samples were collected at the apices of a roughly equilateral triangle with sides one meter long and subsequently mixed together to make a composite sample. The location of each sample was indicated on a topographic base map of the area and geographic coordinates in the form of Latitude and Longitude were recorded using a hand held global position system (GPS). These were subsequently used to produce the sample location map (Figure 3) using Surfer Version 9.1.325 Surface Mapping System (Golden Software, Inc., 2009).

\subsection{In vitro Bioaccessibility Tests}

The soil samples were air dried and sieved to $<60 \mu \mathrm{m}$. Gastric fluids were simulated by adding approximately $60 \mathrm{ml}$ concentrated hydrochloric acid to $2 \mathrm{~L}$ of $0.4 \mathrm{M}$ glycine solution. The glycine solution was prepared by adding $60.06 \mathrm{~g}$ of glycine to $1.9 \mathrm{~L}$ of deionised water and the solution made up to $2 \mathrm{~L}$. The solution was then warmed in an incubator to a temperature of $37{ }^{\circ} \mathrm{C}$ and its $\mathrm{pH}$ adjusted to $1.5 \pm 0.05$ by drop-wise addition of concentrated hydrochloric acid.

The test material ( $1 \mathrm{~g}$ of the $<60 \mu \mathrm{m}$ soil) and $50 \mathrm{ml}$ of the extraction fluid were placed in high density, wide mouthed Nalgene bottles. The bottles were tightly closed and shaken well to ensure that there was no leakage and that no soil was caked at the bottom of the bottle. The bottles were then placed into a temperature controlled incubator $\left(37 \pm 2{ }^{\circ} \mathrm{C}\right)$ and shaken side-to-side at $300 \mathrm{rpm}$ for 1 hour. After 1 hour, the bottles were removed and placed upright on a bench top to allow the soil to settle to the bottom. A $15 \mathrm{ml}$ aliquot of the supernatant was withdrawn using a syringe and filtered using a Luer-Lok attachment fitted with $0.45 \mu \mathrm{m}$ cellulose acetate filter. The filtered solutions were stored in a fridge at $4{ }^{\circ} \mathrm{C}$ until they were analyzed. 


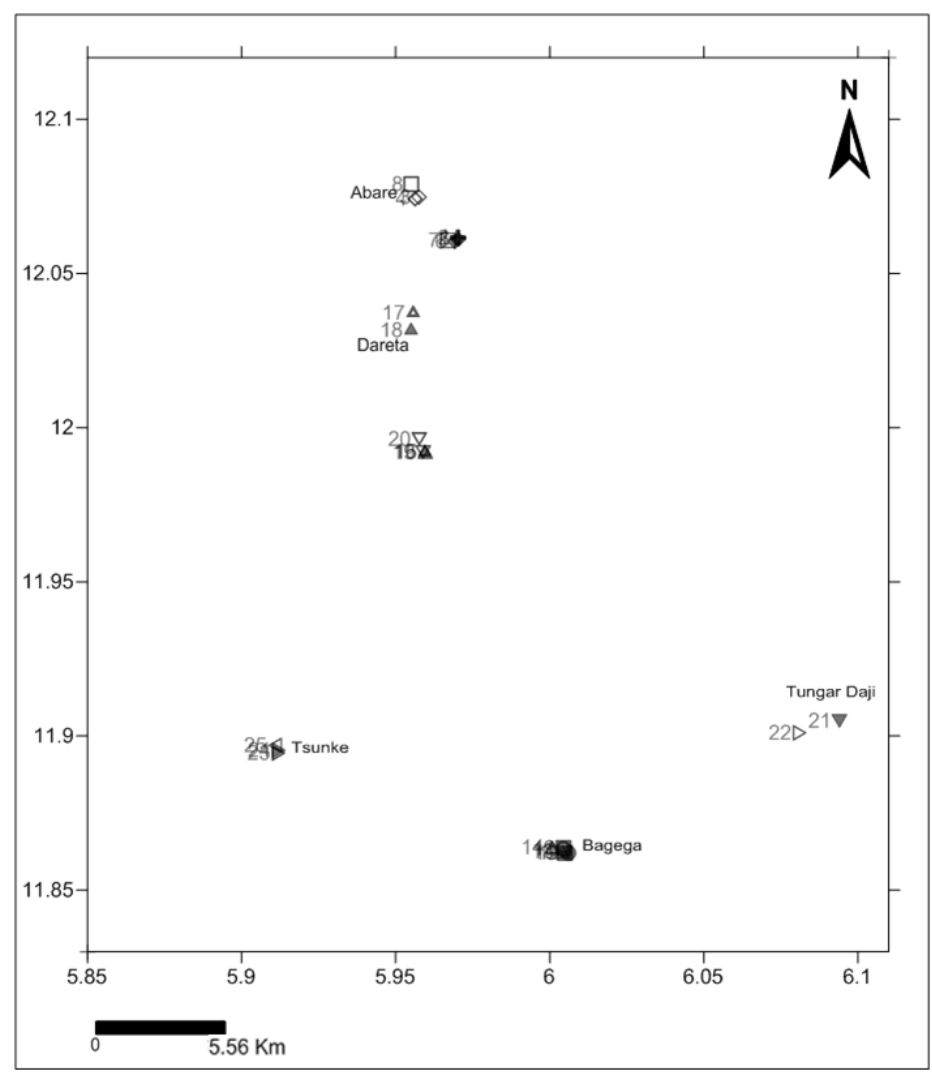

Figure 3. Map of the Anka area showing sampling sites and location of some artisanal mine pits. The location of this area in Nigeria is indicated in Figure 1

\subsubsection{Effect of $\mathrm{pH}$ on In vitro Bioaccessibility}

To test the effect of $\mathrm{pH}$ on lead bioaccessibility, the experiment was repeated at three $\mathrm{pH}$ values; $1.50,2.20$ and 2.90 which were achieved by successively reducing the volume of concentrated hydrochloric acid used (from 60 $\mathrm{ml}$ to $30 \mathrm{ml}$ and $15 \mathrm{ml}$ ) while keeping weight of glycine and total solution volume constant. A set of fifteen samples was used in this study, where three equal aliquots of each sample were each extracted with the solutions of varying $\mathrm{pH}$ in an incubator for one hour at $37^{\circ} \mathrm{C}$ with constant shaking.

\subsubsection{Effect of Solid: Fluid Ratio on In vitro Bioaccessibility}

To test the possibility that ratio of test material weight in the extraction bottle to volume of extraction fluid has an impact on contaminant solubilization, this experiment was conducted using three solid to fluid ratios. In addition to the 1:50 ( $1 \mathrm{~g}$ test material: $50 \mathrm{ml}$ of extraction solution) adopted described above, extraction was also carried out on a sub-set $(\mathrm{n}=10)$ of the samples at $0.5 \mathrm{~g}: 50 \mathrm{ml}$ and $1 \mathrm{~g}: 25 \mathrm{ml}$ test material to extraction solution respectively. The procedure involved placing three aliquots of the test material and adding the required volume of extraction solution. The set-up was then incubated for one hour at $37{ }^{\circ} \mathrm{C}$ with constant agitation: after this 10 $\mathrm{ml}$ aliquots of the supernatant were collected and filtered for analysis.

\subsubsection{Effect of Incubation Time on In vitro Bioaccessibility}

In order to study the effect of incubation time on the in vitro bioaccessibility of contaminant elements, the extraction process was repeated at different time intervals. This was aimed at testing the impact of time of contact between the test material and extraction solution, within the stomach emptying time for a child. For this purpose, a sub-set $(n=10)$ of samples were incubated for one hour and two hours and finally left standing on the bench top for 17 hours. After the first hour, the bottles were removed and placed on the bench top as usual to cool and to allow solids to settle. A $10 \mathrm{ml}$ aliquot was collected and filtered into sample vials before returning the remaining solution to the incubator for another hour with constant agitation: a second $10 \mathrm{ml}$ aliquot was then collected for analysis. A third aliquot was collected after 17 hours standing time. 
All in vitro bioaccessibility solutions were analyzed by inductively coupled plasma-optical emission spectrometry (ICP-OES) using a Varian Vista Pro CCD Simultaneous spectrometer, equipped with a Varian Sample Preparation System (SPS-5). Calibration standards were prepared using commercially available analytical grade stock solutions from Fisher Scientific, UK. In order to the check the quality of the analyses, an analytical spike was included within each batch of samples, coupled with at least three blank samples (milliQ water) in each case: replicate measurements were done on samples selected at random. The analytical blanks gave values generally very close to the LOD for all elements. The residual standard deviation (RSD) for the duplicate measurements on blanks and samples was generally within or slightly above the acceptable limit of $10 \%$ (Lu et al., 2011) or 15\% (Smith et al., 2009), indicating good method precision.

\section{$3.3 \mathrm{X}$-ray Fluorescence Spectrometry}

Total lead concentration in samples was measured using X-ray fluorescence spectrometry. Pressed powder pellets were prepared by mixing $7.5 \mathrm{~g}$ of the sieved, oven-dried sample with three cellulose tablets and grinding the mixture in an agate mill (Retsch RS 200) for 1 minute. The powder was then pressed into $25 \mathrm{~mm}$ pellets using a hydraulic press at a pressure of 20 tons. Analysis was carried out using a high performance sequential wavelength dispersive XRF spectrometer (S4 PIONEER, Bruker AXS, Germany), using the GEO-QUANT program for trace elements, and running on the SPECTRA ${ }^{\text {plus }}$ XRF software. However, for some samples with very high lead contents, beyond the upper calibration range of the GEOQUANT method $(2500 \mu \mathrm{g} / \mathrm{g} \mathrm{Pb})$, a semi-quantitative method was used to estimate total concentrations. This involved preparation of glass beads and determining $\mathrm{Pb}$ as a major oxide. The quantification limit for this method is $0.02 \% \mathrm{~Pb}$. The set-up consists of a $75 \mu \mathrm{m}$ ultra-thin $\mathrm{x}$-ray tube source and a LiF 220 high resolution analyzer crystal detector applicable for Ti or $\mathrm{V}$ $\mathrm{K} \alpha$ to Mo $\mathrm{K} \alpha$ which gives higher resolution and reduces spectrum overlap interferences. In order to check analytical accuracy, four certified reference materials (CRMs) were included among each batch of samples ( $\mathrm{n}=$ 10). These were SDO-1, W2a, MESS-2 and STSD-2 for the trace elements and major elements and the measured concentrations show very good agreement with the certified values, therefore showing good measurement accuracy.

\subsection{Statistical and Graphical Treatment of Data}

The geochemical data was submitted to multivariate statistical analysis using SPSS (PASW 18) for Windows using methods described by Field (2009). Descriptive statistics (DS), correlation matrix (CM) and One-way repeat-measures ANOVA were performed on the data. While carrying out these tests, it was assumed that the data were normally distributed and therefore no normalization was done before statistical treatment. For the repeat-measures ANOVA, a correction for data sphericity was carried out using the Bonferroni method. A correlation matrix was used to obtain the Pearson relationship between parameters. Repeat-measures ANOVA were performed in order to assess the effect of $\mathrm{pH}$, time and solid to fluid ratio on element bioaccessibility.

\section{Results and Discussion}

The bioaccessible concentration of lead in the samples is presented in Table 1, together with the total concentration and the human bioaccessible fraction. Lead concentration in the simulated gastric fluid lies between 197.5 and $41740 \mu \mathrm{g} / \mathrm{g}$ (mean, $9731.7 \pm 12058 \mu \mathrm{g} / \mathrm{g}$ ). The human bioaccessible fraction (HBA\%) which is the proportion of lead that is extracted into the simulated gastric fluid as a percentage of the total concentration in the 25 soil and sediment samples was calculated by:

$$
\% H B A=\frac{\text { Concentration in extraction solution } u g / g}{\text { Total concentrationin sample ug } / g} \times 100
$$

The result is presented in Table 1 and shows that the bioaccessibility of lead ranges from 28.7 to $100.4 \%$ (mean $60.3 \%)$.

The high bioaccessibility of lead across all samples (Table1) is in part a function of the higher total concentration of the element in the samples. However it is also influenced by the abundance of very labile residual lead oxide and lead carbonate minerals in the ores (Plumlee \& Morman, 2011) and also confirmed by strong partitioning of lead into these phases seen during the SEPs experiments. Casteel et al. (2006) have shown that oral lead bioaccessibility in human children is highest in lead carbonates and lead associated with manganese oxides. According to them, lead phosphates and oxide minerals and lead associated with iron oxides show intermediate bioaccessibilities, while lead sulphides and silicates (residual phases) are the least bioaccessible. The mean lead bioaccessibility obtained in this work is very similar to that reported (64\%) for mining contaminated soils in 
Brazil and $75-80 \%$ for a certified reference soil, SRM 2710 by Bosso and Enzweiler (2008) using the PBET method. The mean lead bioaccessibility of $39.1 \%$ for urban soils in Guangzhou, China (Lu et al., 2011) is also within the range obtained here. Similarly, gastric bioaccessibility of between 23 and $69 \%$ obtained in lead-rich mine wastes by Jaggard (2012) are also broadly similar to the results of this work. However the results of this study are higher than median lead bioaccessibility of $23 \%$ for the $<2 \mathrm{~mm}$ and $18 \%$ for $<250 \mu \mathrm{m}$ fractions respectively obtained by Morman et al. (2009) from uncontaminated background soils in the United States, which is perhaps a pointer to the important role mineralogy and total element concentration can play in its bioaccessibility.

Table 1. Total and In vitro bioaccessible concentration along with the human bioaccessible lead (HBA\%) in soils and sediments from Anka area, NW Nigeria

\begin{tabular}{|c|c|c|c|}
\hline Sample & Total $\mathrm{Pb}, \mu \mathrm{gg}^{-1}$ & Bioaccessible $\mathrm{Pb}, \mu_{\mathrm{gg}}{ }^{-1}$ & Human Bioaccessible $\mathrm{Pb}, \%$ \\
\hline $\mathrm{A} 1$ & 61700 & 17702 & 28.7 \\
\hline $\mathrm{A} 2$ & 378 & 247 & 65.3 \\
\hline A4 & 24300 & 14007 & 57.6 \\
\hline A5 & 2023 & 1226 & 60.6 \\
\hline A6 & 76000 & 26948 & 35.5 \\
\hline A7 & 10200 & 10239 & 100.4 \\
\hline A8 & 8500 & 5612 & 66.0 \\
\hline A 10 & 327 & 223 & 68.1 \\
\hline B1 & 122800 & 41740 & 34.0 \\
\hline $\mathrm{B} 2$ & 59100 & 35470 & 60.0 \\
\hline B3 & 28300 & 16173 & 57.1 \\
\hline B4 & 1333 & 697 & 52.3 \\
\hline B5 & 403 & 238 & 59.0 \\
\hline B7 & 2771 & 1574 & 56.8 \\
\hline D1 & 3800 & 1869 & 49.2 \\
\hline D2 & 12100 & 8978 & 74.2 \\
\hline D4 & 1232 & 853 & 69.3 \\
\hline D5 & 2600 & 1705 & 65.6 \\
\hline D7 & 38200 & 23662 & 61.9 \\
\hline D9 & 858 & 566 & 66.0 \\
\hline TS3 & 357 & 249 & 69.8 \\
\hline TS4 & 49400 & 20464 & 41.4 \\
\hline TS5 & 327 & 198 & 60.4 \\
\hline TD6 & 15600 & 12312 & 78.9 \\
\hline TD10 & 497 & 243 & 69.0 \\
\hline Min & 327 & 198 & 28.7 \\
\hline Max & 122800 & 41740 & 100.4 \\
\hline Mean & 17522 & 9732 & 60.3 \\
\hline
\end{tabular}

\subsection{Correlation Analysis}

A Pearson correlation analysis was carried out (significant at $p=0.01$ ) between total elemental concentration in the samples and the bioaccessible concentration. The results indicate that there is a very strong positive correlation between total concentration and bioaccessibility of lead, with a correlation coefficient of 0.94 . In all 
samples, there is a generally positive linear relationship between total lead and bioaccessible lead, except in samples with very high total lead concentration, where the relationship appears to be less linear. The strong relationships which appear to exist between the total and bioaccessible concentrations is a result of the introduction of lead into soils and sediments during the processing of ores, the higher bioaccessibilities occurring because the element had a relatively short time to bind to soil and sediment phases (Button et al., 2009).

\subsection{Physicochemical Controls on Oral Bioaccessibility}

The physicochemical parameters that are likely to affect the oral bioaccessibility of contaminants have been identified by previous workers (e.g. Drexler \& Brattin, 2007) to include the $\mathrm{pH}$ of the extraction solution, extraction temperature, and length of extraction time; the feed or fast status of the individual and the ratio of the extraction fluid to the weight of test material.

\subsubsection{Effect of $\mathrm{pH}$}

The bioaccessibility of lead was measured at three $\mathrm{pH}$ levels. This indicates that $\mathrm{Pb}$ extraction has a linear relationship with the $\mathrm{pH}$ of the extraction solution, generally decreasing as the $\mathrm{pH}$ of the solution increases, except in few samples, especially $\mathrm{B} 2$, where the bioaccessible concentration of $\mathrm{Pb}$ appears to rise with the rising of $\mathrm{pH}$. Repeat Measures ANOVA was performed on this data in order to verify the observations made from the graphs. While the results of this statistical test could not identify the $\mathrm{pH}$ level that was more effective in extracting the elements, it does show that $\mathrm{pH}$ has a significant effect $(\mathrm{p}<0.05)$ on the leaching of $\mathrm{Pb}$. The link between the two data sets is not very clear, but shows that $\mathrm{pH}$ has had an effect on $\mathrm{Pb}$ solubilization.

According to Drexler and Brattin (2007) human gastric pH generally falls between 1 and 4 under fasted conditions, but may reach 5 for a few hours after the intake of food. The $\mathrm{pH}$ range used in this work therefore falls within the fasted range and in general, a reduction in $\mathrm{pH}$ is expected to result in an increase in the dissolution of contaminant elements from an earth material. The effect of gastric $\mathrm{pH}$ is important when assessing the risk associated with ingestion of soil borne toxic elements, especially in economically deprived areas (Bosso \& Enzweiler, 2008). In such areas, irregular feeding habits, often exemplified by the skipping of meals, means stomach $\mathrm{pH}$ remains low enough over long periods of time to ensure effective dissolution of contaminants incidentally ingested by children. Turner (2011) points out, however, that the $\mathrm{pH}$ dependence of mobilization in the gastric environment is metal specific: co-variation of $\mathrm{pH}$ and chloride concentration in the human stomach allows the formation of very soluble metal chlorocomplexes. According to Plumlee and Ziegler (2004), within the acidic human stomach, most base metals, including $\mathrm{Pb}, \mathrm{Fe}, \mathrm{Cu}, \mathrm{Zn}, \mathrm{Cd}, \mathrm{Ni}$ and $\mathrm{Co}$ are likely to be complexed chiefly by chloride. Turner (2011) reports that the accessibilities of $\mathrm{Cr}$ and $\mathrm{Pb}$ are more sensitive to $\mathrm{pH}$, showing significant reduction in going from low to high $\mathrm{pH}$, but $\mathrm{Zn}$ accessibility is comparatively less affected. This is similar to the results of this work, which show $\mathrm{Pb}$ accessibility decreasing with increasing $\mathrm{pH}$.

\subsubsection{Effect of Incubation Time}

Three sample incubation times were used to assess the effect of extraction time on accessibilities of elements in soils against the background of the reported half-time of stomach emptying time in human beings of about 1 hour (Washington et al., 2001). The results presented in Figure 4 show that the accessibility of $\mathrm{Pb}$ remained unchanged over the entire period and repeated Measures ANOVA analysis $(p<0.05)$ indicates the length of extraction time was not a significant factor affecting $\mathrm{Pb}$ solubilization. Stomach emptying rate or residence time is said to be a complex function of the degree of smooth muscle stimulation, humoral signalling in the gut, food composition if present, time of day and other physiological factors (Drexler \& Brattin, 2007). Whatever the factors controlling stomach emptying, it does appear that longer extraction time does not enhance the accessibility of lead. This is consistent with the results of Drexler and Brattin (2007) and USEPA (2008) who found no significant difference in the In vitro bioaccessibility of $\mathrm{Pb}$ when the time was varied from 1 to 4 hours. 


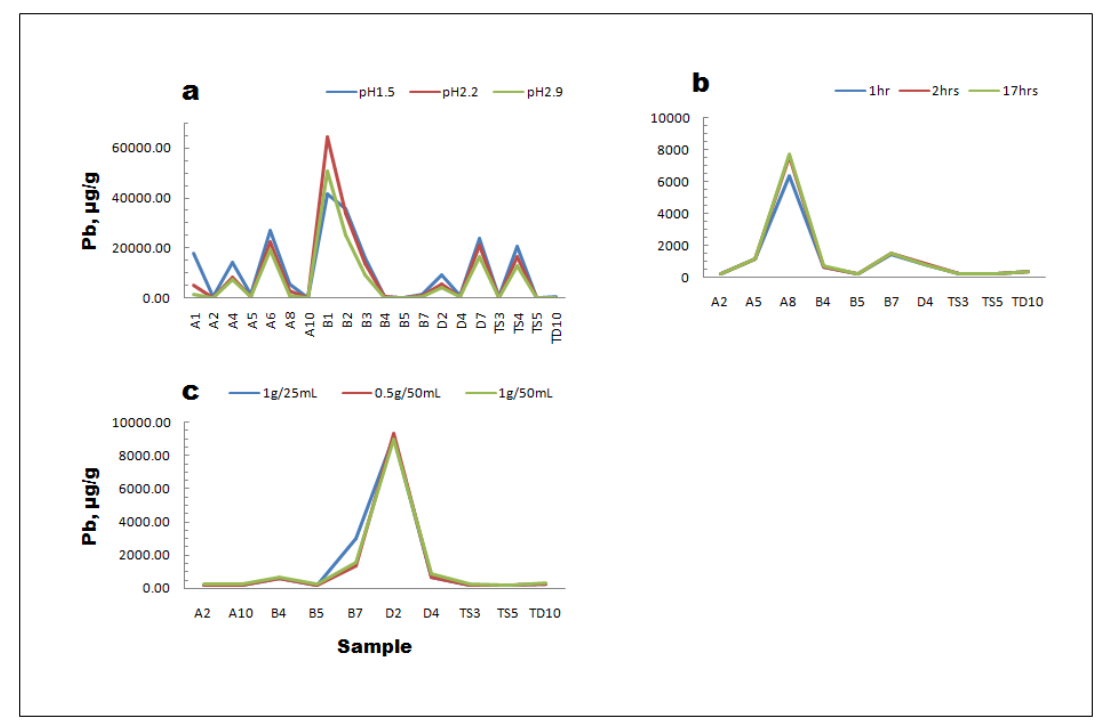

Figure 4. Effects of physicochemical parameters on the In vitro bioaccessibility of lead in contaminated soils

\subsubsection{Effect of Solid: Fluid Ratio}

The ratio of fluids to solid in the human stomach varies depending on feeding status and the amount of contaminated earth material ingested. The effect of solid/fluid ratio on the accessibility of lead was investigated using three combinations of the test material to the extraction fluid. The results (Figure 4) show that mobilization of $\mathrm{Pb}$ did not appear to change with variation in the ratio of solid sample to extraction fluid volume. Results of One-way Repeat Measures ANOVA support this $[\mathrm{F}(1.12,10.06)=0.65, \mathrm{p}>0.05]$.

A wide range of ratios have been reported in the literature, ranging from 1: 100 to 1: 500 (Turner, 2011) and as high as 1: 1000 (Wragg et al., 2011). Drexler and Brattin (2007) performed tests on a variety of standard reference materials and reported no significant variation in the in vitro bioaccessibility with soil masses as low as $0.2 \mathrm{~g}$ per $100 \mathrm{ml}$ of extraction fluid (1:500). Because actual test materials may not be as homogenous as reference materials and because of weighing errors, they proposed a ratio of no less than $0.4 \mathrm{~g}$ test material per $100 \mathrm{ml}$ of fluid to reduce possible variability in bioaccessibility. However, Wragg et al. (2011) have reported the use of a ratio of 1: 1000 in order to eliminate poor reproducibility occasioned by high. As concentration in soils contaminated with mine wastes and slag, although they too acknowledged the possible effects of sample inhomogeneity. The use of ratios of between 1:25 to 1: 100 (Figure 4) in this work did not result in a significant difference in lead bioaccessibility. The comparatively lower total $\mathrm{Pb}$ concentration in samples used for this experiment may have helped to avoid the problem of extraction fluid saturation and lead chloride precipitation (Drexler \& Brattin, 2007; USEPA, 2008) reflected in samples with highly soluble Pb minerals such as lead acetate, lead oxide and lead carbonates. Even when a ratio of $1 \mathrm{~g}$ in $25 \mathrm{ml}$ fluid was used, no significant difference was observed despite of the presence of more sample mass and surface area. Unless one is dealing with highly contaminated samples exceeding the $50,000 \mu \mathrm{g} \mathrm{Pb} / \mathrm{g}$ limit set by previous workers, it appears that the ratios used in this work are acceptable when there is limited sample supply.

\subsection{Contaminant Daily Intake}

The chemical or contaminant daily intake is used to assess the exposure of humans, especially children to contaminant elements through ingestion of contaminated soil. For a child 2 to 6 years old, weighing $17.8 \mathrm{~kg}$ (USEPA, 1997), the daily chemical intake (CDI, $\mu \mathrm{g} \mathrm{kg}^{-1} \mathrm{day}^{-1}$ ) is calculated using the following formula:

$$
C D I=\frac{C S \times I R \times B A \times E F}{B W} \times C F
$$

where CS is the total concentration of the contaminant element in the sample $(\mu \mathrm{g} / \mathrm{g})$, IR is the ingestion rate set at (USEPA, 2002) $200 \mathrm{mg}$ soil per day, BA is the mean bioaccessibility of the element in the test materials, EF represent the exposure frequency, in this case 0.5 (182 days per year, Hemond \& Solo-Gabriele, 2004), BW denotes body weight and $\mathrm{CF}$ is the unit conversion factor $\left(10^{-3}\right)$. 
The CDI estimates show that children exposed to these soils are likely to ingest between 110 to $41,585 \mu \mathrm{g} \mathrm{Pb} / \mathrm{kg}$ per day with a mean of $7,086 \mu \mathrm{g} \mathrm{Pb} / \mathrm{kg}$ of body weight daily. These figures grossly exceed the tolerable daily intake (TDI) of $\sim 3.6 \mu \mathrm{g} / \mathrm{kg} /$ day for lead calculated from a provisional tolerable weekly intake (PTWI) of 25 $\mu \mathrm{g} / \mathrm{kg}$ body weight (DEFRA, 2002). The results show that at all the sample sites, the tolerable daily intake of $\mathrm{Pb}$ is far exceeded. This may explain the excessively high blood lead levels reported by the Blacksmith Institute (2010) in children of the affected villages leading to high levels of childhood mortalities. This is brought about by a combination of high total lead concentration in the soils, especially within living compounds and sediments of the area and the abundance of highly soluble secondary lead carbonate and lead oxide minerals within the ores (Plumlee \& Morman, 2011).

This estimate is based on an assumption that the only way of transmission is through the ingestion of fine particles which stick to the hands of children. But the daily ingestion of soil in these villages may be higher than the conservative figure of $200 \mathrm{mg}$ of soil per day used in this work, due to the possibility of other routes of exposure, such as eating poorly washed vegetables and the deliberate ingestion of soil. Where poor people live in contaminated areas, sub-nutrition and direct contact with wastes and soils are common (Bosso \& Enzweiler, 2008). This may result in the ingestion of up to $10 \mathrm{~g}$ of soil in a single day (USEPA, 2002) leading to much higher contaminant uptake. If the latter scenario is taken into account, the health risks posed by the ingestion of these soils will be much higher than this data indicates, considering especially the very high levels of bioaccessible lead.

\section{Conclusions}

In vitro bioaccessibility measurements based on hand-to-mouth ingestion of soils in the contaminated Anka villages has shown high $\mathrm{Pb}$ concentrations. The higher concentration obtained in vitro is a function of the lower $\mathrm{pH}$ of the simulated gastric fluids, and in nature, bioaccessibility may be further enhanced by the near anoxic condition of the human stomach. The chemical daily intake (CDI), computed for children in the Anka area based on hand-to-mouth ingestion of contaminated soil shows that the tolerable daily limit for $\mathrm{Pb}$ has been exceeded. The mean $\mathrm{CDI}$ for $\mathrm{Pb}$ was found to be nearly 2000 times the tolerable daily intake for a $2-6$ year child weighing $17.8 \mathrm{~kg}$; the minimum value being about 31 times the limit. These results highlight the severity of the contamination of soils in the affected villages. Hand-to-mouth ingestion is the only exposure scenario investigated in this study. However, given the poor socioeconomic status of the residents of this study area, children and even adults can be exposed to lethal doses of lead and other PTEs through consumption of improperly washed vegetables, inhalation of indoor and outdoor dusts and drinking contaminated surface water. Similarly, factors such as low body weights due to sub-nutrition together with poor sanitation, which may increase the exposure frequency, are likely to increase the risks. While high blood lead levels have been reported in children in these villages by a combined team from the UNEP/OCHA, Blacksmiths Institute and other organizations, it will be interesting to study adult subjects, especially those actively involved with ore processing in order to assess possible chronic $\mathrm{Pb}$ and other PTE toxicity.

The results underscore the need to study more closely, the effects of artisanal mining and processing of ores on the quality of the environment and the attendant human health consequences. Determining the spatial distribution of mining related potentially toxic elements relative to baseline concentrations, together with an assessment of their geochemical partitioning and in vitro bioaccessibility would be useful for artisanal mining areas in Nigeria and other parts of the developing world. The knowledge gained can guide remediation efforts and help to mitigate the harm to resident populations of contaminated areas.

\section{Acknowledgements}

This research was carried out at the School of Environmental Sciences, University of East Anglia, Norwich, UK when NMW was a Postgraduate Research Student. We are grateful to the Petroleum Technology Development Fund (PTDF), Nigeria for funding the work under the Overseas Scholarship Scheme.

\section{References}

Adamo, P., Di, S., Wison, M. J., \& Mchardy, W. J. (1996). Chemical and mineralogical forms of Cu and Ni in contaminated soils from the Sudbury mining and smelting region, Canada. Environ Poll, 91, 11-19. http://dx.doi.org/10.1016/0269-7491(95)00035-P

Adriano, C. D. (1986). Heavy metals in terrestrial environment. Berlin: Springer.

Alloway, B. J. (1995). Heavy metals in soils. London: Chapman and Hall publishers. http://dx.doi.org/10.1007/978-94-011-1344-1

Anju, M., \& Banerjee, D. K. (2010). Comparison of two sequential extraction procedures for heavy metal 
partitioning in mine tailings. Chemosphere, 1393-1402. http://dx.doi.org/10.1016/j.chemosphere.2009.12.064

Appleton, J. D., Williams, T. M., Orbea, H., \& Carrasco, M. (2001). Fluvial contamination associated with artisanal gold mining in the Ponce Enriquez, Portovelo-Zaruma and Nambija areas, Ecuador. Water Air Soil Poll, 131, 19-39. http://dx.doi.org/10.1023/A:1011965430757

Babut, M., Sekyi, R., Rambaud, A., Potin-Gautier, M., Tellier, S., Bannerman, W., \& Beinhoff, C. (2003). Improving the environmental management of small-scale gold mining in Ghana: a case study of Dumasi. Journal of Cleaner Production, 11(2), 215-221. http://dx.doi.org/10.1016/S0959-6526(02)00042-2

BARGE (The Bioaccessibility Research Group of Europe). (2008). Retrieved from www.bgs.ac.uk/barge

Bird, G., Brewer, P. A., Macklin, M. G., Balteanu, D., Driga, B., Serban, M., \& Zaharia, S. (2003). The solid state partitioning of contaminant metals and As in river channel sediments of the mining affected Tisa drainage basin, northwestern Romania and eastern Hungary. Applied Geochemistry, 18(10), 1583-1595. http://dx.doi.org/10.1016/S0883-2927(03)00078-7

Blacksmith Institute. (2011). Lead poisoning crisis in Nigeria, Project Completion Report. Retrieved from http://www.blacksmithinstitute.org/files/FileUpload/files/Additional\%20Reports/Zamfara_Nigeria_PCR\%2 0April\%202011.pdf

Bosso, S. T., \& Enzweiler, J. (2008). Bioaccessible lead in soils, slag and mine wastes from an abandoned mining district in Brazil. Environ Geochem Health, 30, 219-229. http://dx.doi.org/10.1007/s10653-007-9110-4

Bruker Advanced X-rays Solutions. (2004). Introduction to x-ray fluorescence analysis (XRF). User's manual.

Button, M., Watts, M. J., Cave, M. R., Harrington, C. F., \& Jenkin, G. T. (2009). Earthworms and in vitro physiologically-based extraction tests: complementary tools for a holistic approach towards understanding risk at arsenic-contaminated sites. Environmental geochemistry and health, 31(2), $273-282$. http://dx.doi.org/10.1007/s10653-008-9208-3

Cave, M., Wragg, J., Klinck, B., Gron, C., Oomen, A., Van de Wiele, T., ... Tack, K. (2006). Preliminary assessment of a unified bioaccessibility method for potentially harmful elements in soils. Epidemiology, 17(6), S39. http://dx.doi.org/10.1097/00001648-200611001-00062

Danbatta, U. A., Abubakar, Y. I., \& Ibrahim, A. A. (2009). Geochemistry of gold deposits in the Anka Schist Belt, north-western Nigeria. Nigerian Journ. Chem. Res, 14, 19-29.

DEFRA \& E A. (2002). Contaminants in soils: Collation of toxicological data and intake values for humans. R\&D Publications Tox 4 Chromium; Tox 6 Lead.

Dolenec, T., Serafimovski, T., Tasev, G., Dobnikar, M., Dolenec, M., \& Rogan, N. (2007). Major and trace element in paddy soil contaminated by $\mathrm{Pb}-\mathrm{Zn}$ mining: a case of Kocani Field, Macedonia. Environ Geochem Health, 29, 21-32. http://dx.doi.org/10.1007/s10653-006-9057-x

Dooyema, C. A., Neri, A., Lo, Y. C., Durant, J., Dargan, P. I., Swarthout, T., ... Brown, M. J. (2012). Outbreak of fatal childhood lead poisoning related to artisanal gold mining in northwestern Nigeria, 2010. Environmental health perspectives, 120(4), 601. http://dx.doi.org/10.1289/ehp.1103965

Drexler, J. W., \& Brattin, W. J. (2007). An In Vitro procedure for estimation of lead relative bioavailability: with validation. Human. Ecol. Risk Assess, 13, 383-401. http://dx.doi.org/10.1080/10807030701226350

Federal Surveys of Nigeria. (1967). Quarter degree topographic maps of Kwaimbana SE (sheet 100SE) and Kushaka NE (sheet 122NE).

Garba, I. (2003). Geochemical characteristics of mesothermal gold mineralization in the Pan-African (600 \pm 150Ma) basement of Nigeria. Trans. Inst. Min. Metall, 112, 319-325.

Hemond, H. F., \& Solo-Gabriele, H. M. (2004). Children's exposure to arsenic from CCA-treated wooden decks and playground structures. Risk Anal., 24, 51-64. http://dx.doi.org/10.1111/j.0272-4332.2004.00411.x

Hickey, M. G., \& Kittrick, J. A. (1984). Chemical partitioning of cadmium, copper, nickel and zinc in soils and sediments containing high levels of heavy metals. Journal of Environmental Quality, 13(3), $372-376$. http://dx.doi.org/10.2134/jeq1984.00472425001300030010x

Hilson, G. (2002). The environmental impact of small-scale mining in Ghana: identifying problems and possible solutions. The Geogr. Jour., 168(1), 57-72. http://dx.doi.org/10.1111/1475-4959.00038 
Hinton, J. H., Veiga, M. M., Tadeu, A., \& Veiga, C. (2003). Clean artisanal gold mining: a utopian approach? Jour. Cleaner Prod., 11, 99-115. http://dx.doi.org/10.1016/S0959-6526(02)00031-8

Hudson-Edwards, K. A., Jamieson, H. E., \& Lottermoser, B. G. (2011). Mine wastes: past, present, future. Elements, 7(6), 35-380. http://dx.doi.org/10.2113/gselements.7.6.375

Jaggard, H. N. (2012). Mineralogical characterization of tailings and respirable dust from lead-rich mine waste and its control on bioaccessibility (Master thesis). Queen's University, Ontario.

Jung, M. C. (2001). Heavy metal contamination of soils and waters in and around the Imcheon Au-Ag mine, Korea. Appl Geochem, 16, 1369-1375. http://dx.doi.org/10.1016/S0883-2927(01)00040-3

Kuo, S., Heilman, P. E., \& Baker, A. S. (1983). Distribution and forms of copper, zinc, iron and manganese in soils near a copper smelter. Soil Science, 135, 101-109. http://dx.doi.org/10.1097/00010694-198302000-00004

Li, X., \& Thornton, I. (2001). Chemical partitioning of trace and major elements in soils contaminated by mining and smelting activities. Appl. Geochem. 16, 1693-1706. http://dx.doi.org/10.1016/S0883-2927(01)00065-8

Li, X., Poon, C., \& Liu, P. S. (2001).Heavy metal contamination of urban soils and street dusts in Hong Kong. Appl. Geochem. 16, 1361-1368. http://dx.doi.org/10.1016/S0883-2927(01)00045-2

Lu, Y., Yin, W., Huang, L., Zhang, G., \& Zhao, Y. (2011). Assessment of bioaccessibility and exposure risk of arsenic and lead in urban soils of Guangzhou City, China. Environ Geochem Health, 33, 93-102. http://dx.doi.org/10.1007/s10653-010-9324-8

Martley, E., Gulson, B., Louie, H., Wu, M., \& Di, P. (2004). Metal partitioning in soil profiles in the vicinity of an industrial complex, New South Wales, Australia. Geochem: Explor. Environ. Anal, 4, 171-179. http://dx.doi.org/10.1144/1467-7873/03-030

McCurry, P., \& Wright, J. B. (1977). Geochemistry of calcalkaline volcanics in north-western Nigeria and a possible Pan-African suture zone. Earth Planetary Science Letters, 37, 90-96. http://dx.doi.org/10.1016/0012-821X(77)90149-2

Medlin, E. A. (1997). An in vitro method for estimating the relative bioavailability of lead in humans (Master thesis). University of Colorado, Boulder.

Morman, S. A., Plumlee, G. S., \& Smith, D. B. (2009). Application of in vitro extraction studies to evaluate element bioaccessibility in soils from a transect across the United States and Canada. Appl. Geochem, 24, 1454-1463. http://dx.doi.org/10.1016/j.apgeochem.2009.04.015

Olade, M. A. (1987). Dispersion of Cadmium, Lead and Zinc in Soils and Sediments of a Humid Tropical Ecosystem in Nigeria. In T. C. Hutchinson \& K. M. Meema (Eds.), Lead, mercury, cadmium and arsenic in the environment, scope, 31, 303-313.

Plumlee, G. S., \& Morman, S. A. (2011). Mine wastes and human health. Elements, 7(6), 399-404. http://dx.doi.org/10.2113/gselements.7.6.399

Plumlee, G. S., \& Ziegler, T. L. (2004). The Medical Geochemistry of Dusts, Soils and Other Earth Materials. In B. S. Holland \& K. K. Turekian (Eds.), Treatise on Geochemistry, 9, 263-310.

Ruby, M. V., Schoof, R., Brattin, W., Goldade, M., Post, G., \& Harnois, M. (1999). Advances in evaluating the oral bioavailability of inorganics in soil for use in human health risk assessment. Environ. Sci. Technol., 33, 3697-3705. http://dx.doi.org/10.1021/es990479z

Russ, W. (1957). The geology of parts of Niger, Zaria and Sokoto Provinces. Geological Survey of Nigeria Bulletin, 27, 35.

Singh, A. K., Hasnain, S. I., \& Banerjee, D. K. (1999). Grain size and geochemical partitioning of heavy metals in sediments of the Damodar River-a tributary of the lower Ganga, India. Environmental geology, 39(1), 90-98. http://dx.doi.org/10.1007/s002540050439

Tessier, A., Campbell, P. G. C., \& Bisson, M. (1979). Sequential extraction procedures for the speciation of particulate trace metals. Anal. Chem., 51, 844-851. http://dx.doi.org/10.1021/ac50043a017

Turner, A. (2011). Oral bioaccessibility of trace metals in household dust: a review. Environ. Geochem. Health, 33, 331-341. http://dx.doi.org/10.1007/s10653-011-9386-2

Turner, D. C. (1983). Upper Proterozoic schist belts in the Nigerian sector of the Pan-African province of West Africa. Precambrian Res., 21, 55-79. http://dx.doi.org/10.1016/0301-9268(83)90005-0 
Ullrich, S. M., Ramsey, M. H., \& Helios-Rybicka, E. (1999). Total and exchangeable concentrations of heavy metals in soils near Bytom, an area of $\mathrm{Pb} / \mathrm{Zn}$ mining and smelting in Upper Silesia, Poland. Appl. Geochem., 14, 187-196. http://dx.doi.org/10.1016/S0883-2927(98)00042-0

UNEP/OCHA Environment Unit. (2010). Lead pollution and poisoning crisis, Environmental Emergency Response Mission, Zamfara State, Nigeria. Retrieved from http://ochaonline.un.org/OchalinkClick.aspx?link=ocha\&docld=1178375

USEPA. (1997). Exposure factors handbook volume 1: General factors; EPA/600/P-95/002Fa. Washington D.C: Office of Research and Development, US Government Printing Office.

USEPA. (2002). Child-specific exposure factors handbook, EPA/600/P.00/002B. Washington D. C.: National Centre for Environmental Assessment.

USEPA. (2007a). Guidance for evaluating the oral bioavailability of metals in soils for use in human risk assessment. OSWER 9285.7-80.

USEPA. (2007b). Estimation of relative bioavailability of lead in soil and soil-like materials using in vivo and in vitro methods. OSWER 9285.7-77.

USEPA. (2008a). Mine Waste Technology Program: Linking Waterfowl with Contaminant Speciation in Riparian Soils. EPA/600/R-08/060.

USEPA. (2008b). Standard Operating Procedure for an In Vitro Bioaccessibility Assay for Lead in Soil. EPA 9200.

Washington, N., Washington, C., \& Wilson, C. (2001). Physiological Pharmaceutics: Barriers to drug absorption. New York: Taylor and Francis.

Wragg, J., Cave, M., Basta, N., Brandon, E., Casteel, S., Denys, S., ... Van de Wiele, T. (2011). An inter-laboratory trial of the unified BARGE bioaccessibility method for arsenic, cadmium and lead in soil. Science of the Total Environment, 409(19), 4016-4030.

\section{Copyrights}

Copyright for this article is retained by the author(s), with first publication rights granted to the journal.

This is an open-access article distributed under the terms and conditions of the Creative Commons Attribution license (http://creativecommons.org/licenses/by/3.0/). 